\title{
Hospital-acquired Urosepsis Caused by Achromobacter xylosoxidans
}

\author{
Achromobacter xylosoxidans'ın Neden Olduğu Hastane Kaynaklı Ürosepsis
}

\author{
Aslıhan DEMirel1, Neşe inAN2, Haluk AKPINAR3, Nur EFE İRis1 \\ 1 istanbul Bilim University Faculty of Medicine, Department of Infectious Diseases and Clinical Microbiology, istanbul, Turkey \\ 2istanbul Bilim University Faculty of Medicine, Department of Medical Microbiology, Istanbul, Turkey \\ 3istanbul Bilim University Faculty of Medicine, Department of Urology, Istanbul, Turkey
}

\section{Abstract}

Achromobacter xylosoxidans is a microorganism found in the nature, soil and water. It may cause opportunistic infections in immunosuppressed patients. It may lead rarely to urinary system infections in patients with underlying urinary abnormalities. We report a case of urosepsis due to $A$. xylosoxidans in a 59-year-old female patient having had total bilateral salpingo-oophorectomy seven years ago due to the diagnosis of endometrial clear cell carcinoma.

Keywords: Healthcare-associated infection, sepsis, bacteremia, urinary tract infection, infection

\section{$\ddot{0} \mathrm{z}$}

Achromobacter xylosoxidans doğada, toprak ve suda bulunabilen bir mikroorganizmadır. İmmün sistemi baskılanmış hastalarda fırsatçı enfeksiyonlara neden olabilir. Üriner sistem anomalileri olan hastalarda nadiren üriner sistem enfeksiyonlarına yol açabilir. Bu olgu sunumunda 59 yaşında, kadın, endometriyum berrak hücreli karsinom tanısıyla yedi yıl önce total bilateral salpingooferektomi yapılmış bir hastada $A$. xylosoxidans ürosepsisi sunulmaktadır.

Anahtar kelimeler: Sağlık bakımı ile ilgili enfeksiyon, sepsis, bakteremi, üriner sistem enfeksiyonu, infeksiyon

\section{Introduction}

Achromobacter xylosoxidans is a Gram-negative aerobic, oxidase-positive bacterium that can be found in soil and water in nature[1,2]. It may lead to opportunistic infections, such as bacteremia, meningitis, pneumonia and peritonitis, especially in patients with underlying diseases and immunosuppression[2]. Although it is not a frequently seen non-fermentative bacillus, there are several reports describing nosocomial infections by means of contamination of some medical solutions, such as dialysis fluid, chlorhexidine, and deionized water $[3,4]$. In addition, $A$. xylosoxidans has gained more importance recently since it may be resistant to cephalosporins, aminoglycosides, and quinolones[5,6]. In this paper, we present a case of urosepsis due to $A$. xylosoxidans.

\section{Case Presentation}

A 59-year-old female patient with a history of total bilateral salpingo-oophorectomy + radiotherapy seven years ago due to endometrial cell carcinoma and ureterolithotripsy for left ureterolithiasis two years ago was admitted to the Urology Clinic with the complaint of macroscopic hematuria. The patient had undergone transurethral resection of a bladder tumor (TUR-T) and clot evacuation because of a suspicious mass detected on pelvic magnetic resonance imaging (MRI) one month ago (pathological examination of the specimen did not reveal malignancy). Bladder irrigation and hyperbaric oxygen treatment were applied and four units of erythrocyte suspension were transfused. As hematuria could not be stopped, hematoma in the bladder was evacuated by means of cystoscopy. On the seventh day of hospitalization, the patient had fever 
(tympanic temperature of $39{ }^{\circ} \mathrm{C}$ ) and empirical treatment with cefuroxime axetil $(250 \mathrm{mg}, \mathrm{POq} 12 \mathrm{H})$ was started. As the fever did not subside on the $3^{\text {th }}$ day of antibiotherapy, infectious diseases consultation was requested. The patient did not have any symptoms other than hematuria and dry cough. Systematic physical examination revealed only crackles over the left lower lung area. Blood pressure was 110/70 $\mathrm{mmHg}$; pulse rate was 90/ min and oxygen saturation level was $96 \%$. The laboratory results were as follows: leukocyte: $4590 / \mathrm{mm}^{3}$, absolute neutrophil count: $3777 / \mathrm{mm}^{3}$, hemoglobin: $9 \mathrm{~g} / \mathrm{dL}^{2}$ hematocrit: $26.8 \%$, platelet; $37000 / \mathrm{mm}^{3}$, C-reactive protein (CRP) $=9 \mathrm{mg} / \mathrm{dL}(\mathrm{n}<0.5$ $\mathrm{mg} / \mathrm{dL}$ ), serum creatinine $=1.04 \mathrm{mg} / \mathrm{dL}$. After obtaining blood and urine cultures, empirical therapy with meropenem $(1 \mathrm{~g}$, intravenous $\mathrm{q} 8 \mathrm{H}$ ) was initiated with the presumed diagnosis of sepsis. Blood cultures revealed Gram-negative coccobacilli (BacT/ALERT 3D (bioMérieux France) system). Gram-negative coccobacilli of 80.000 colony-forming unit $/ \mathrm{mL}$ were also isolated from urine. The colonies grew on chocolate-agar were whitish-gray, smooth and mucoid (Figure 1, 2). Conventional biochemical tests were applied for identification. The isolate was oxidase-positive, and non-fermentative. Indole and catalase tests were negative. In addition it was motile and its culture on triple sugar iron was $\mathrm{H}_{2} \mathrm{~S}$-negative. The bacillus was identified as A. xylosoxidans by MicroScan kit (Beckman Coulter, USA). Antibiotic susceptibilities were performed according to the Clinical and Laboratory Standards Institute guidelines using the M2-A9 standard by Kirby-Bauer disc diffusion method[7]. It was susceptible to co-trimoxazole, ticarcillin, amoxicillinclavulanic acid, piperacillin-tazobactam, ciprofloxacin, ceftazidime, meropenem and resistant to aztreonam, amikacin, and gentamicin (Table 1). Fever subsided in the $48^{\text {th }}$ hour and the patient recovered on $6^{\text {th }}$ day of treatment. The urine culture performed on the $3^{\text {rd }}$ day of treatment remained sterile. The CRP

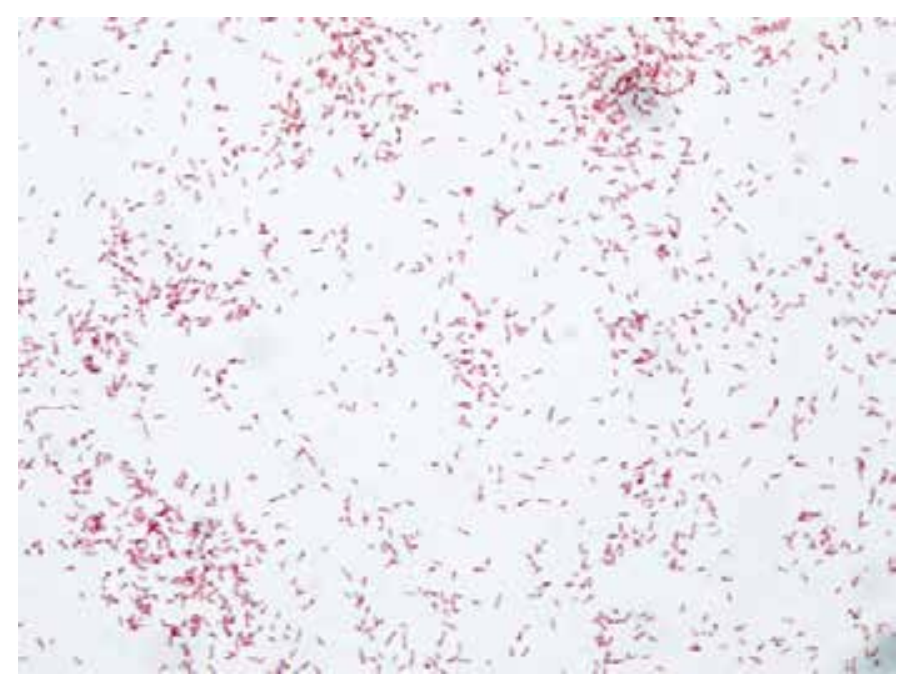

Figure 1. Colonies of Achromobacter xylosoxidans, growing on chocolate agar level decreased to $2.6 \mathrm{mg} / \mathrm{dL}(\mathrm{n}<0.5 \mathrm{mg} / \mathrm{dL})$, and the patient was discharged on her own free will on the $7^{\text {th }}$ day. Meropenem was shifted to oral trimethoprim sulfamethoxazole (Double strength tablet, bid) and the treatment was continued to complete 21 days.

\section{Discussion}

A. xylosoxidans, previously known as Alcaligenes xylosoxidans, is a Gram-negative, aerobic, oxidase-positive, non-fermentative, motile bacillus mostly encountered in soil and water $[1,2]$. $A$.

Table 1. Antimicrobial susceptibility test results of Achromobacter xylosoxidans strain

\begin{tabular}{ll}
\hline Antimicrobial drug & $\begin{array}{l}\text { Minimum inhibitory } \\
\text { concentration }(\mu \mathrm{g} / \mathrm{ml})\end{array}$ \\
\hline Amikacin & $>32(\mathrm{R})$ \\
\hline Aztreonam & $>16(\mathrm{R})$ \\
\hline Cefepime & $\leq 8(\mathrm{~S})$ \\
\hline Ceftazidime & $4(\mathrm{~S})$ \\
\hline Ceftriaxone & $32(\mathrm{I})$ \\
\hline Ciprofloxacin & $\leq 1(\mathrm{~S})$ \\
\hline Gentamicin & $>8(\mathrm{R})$ \\
\hline Imipenem & $\leq 4(\mathrm{~S})$ \\
\hline Levofloxacin & $\leq 2(\mathrm{~S})$ \\
\hline Meropenem & $\leq 4(\mathrm{~S})$ \\
\hline Piperacilin-tazobactam & $\leq 16(\mathrm{~S})$ \\
\hline Tetracycline & $>8(\mathrm{R})$ \\
\hline Ticarcillin-clavulanic acid & $\leq 16(\mathrm{~S})$ \\
\hline Trimethoprim-sulfamethoxazole & $\leq 2 / 38(\mathrm{~S})$ \\
\hline S: Suscetbl:
\end{tabular}

S: Susceptible, I: Intermediate, R: Resistant

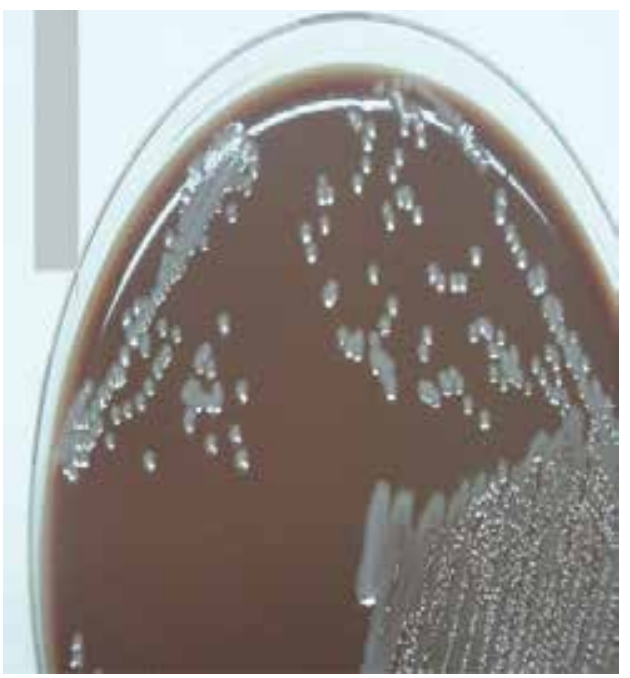

Figure 2. Gram-negative appearence of the bacteria with Gram stain 
xylosoxidans has been reported to be isolated from many body fluids, such as blood, urine, sputum, cerebrospinal fluid and wound swab[1]. It was first isolated from purulent ear drainages from seven patients with chronic otitis media in 1971 by Yaabuuchi and Ohyama[8]. It is among the etiologic agents of opportunistic infections in patients with underlying diseases and immunosuppression. Besides, it may lead to nosocomial infections by means of contaminated solutions ${ }^{[3-5]}$. Central venous catheter use is also among the risk factors for the development of $A$. xylosoxidans infections[6]. Severe sepsis and septic shock due to $A$. xylosoxidans bacteremia in hemodialysis patients resulting in death have been reported $[4,9,10]$. Aisenberg et al.[11] identified $A$. xylosoxidans as the causative agent of bacteremia in 46 patients with cancer between 1989 and 2003. Sixty-seven percent of these patients had hematological malignancy; 52\% had neutropenia, 26\% had a history of high-dose steroid intake, and 26\% had diabetes mellitus[11]. A. xylosoxidans rarely leads to urinary system infections. Tena et al.[12] demonstrated that seven of nine patients with A. xylosoxidans urinary tract infection had underlying urinary system abnormalities[12]. Our patient who had a history of surgery and radiotherapy, had multiple urological interventions, and the agent was isolated as the cause of urosepsis.

A. xylosoxidans has been reported to show high-level of resistance to cephalosporins $(>90 \%)$, aminoglycosides $(>90 \%)$ and quinolones $(>80 \%)^{[13]}$. In a study performed by Aisenberg et al.[11], all the isolates were susceptible to meropenem and piperacillin-tazobactam; 98\%, 94\% and 87\% were susceptible to ticarcillin-clavulanic acid, trimethoprim-sulfamethoxazole and imipenem, respectively. More than 90\% of isolates were resistant to cephalosporins (Except for ceftazidime and cefoperazone; susceptibility rates of $92 \%$ and $96 \%$ respectively) $94 \%$ were resistant to aztreonam, 92\% - to tobramycin, $89 \%$ - to gentamicin and $90 \%$ were resistant to amikacin[11]. Tena et al.[12] demonstrated that all isolates were susceptible to imipenem and piperacillin-tazobactam, $88.8 \%$ to ceftazidime and $77.7 \%$ were susceptible to trimethoprim-sulfamethoxazole, whereas all the isolates were resistant to ampicillin and cefuroxime, $89 \%$ - to norfloxacin, 78\% - to ciprofloxacin, and 67\% were resistant to gentamicin[12]. Turel et al.[6], reported an A. xylosoxidans-related outbreak in a newborn intensive care unit. Thirty-four isolates were identified and all of them were susceptible to meropenem and trimethoprim-sulfamethoxazole, $91 \%$ - to piperacillintazobactam, 82\% - to ciprofloxacin and ceftazidime, 15\% - to cefepime and, none of them were susceptible to gentamicin[6]. Susceptibility pattern of the isolate in our case was similar to the results reported by Aisenberg et al.[11], Tena et al.[12] and Turel et al.[6]. Empirical treatment with cefuroxime was initiated by a physician who was not an infectious diseases specialist and it was not an appropriate drug in this case. After the consultation with infectious diseases specialists, the antibiotherapy was switched to meropenem. The patient recovered completely with meropenem for seven days followed by oral co-trimoxazole therapy for an additional two weeks[11,12],

In conclusion, A. xylosoxidans is an opportunistic pathogen that may cause infections, such as bacteremia, meningitis, and pneumonia in patients with immunosuppression and underlying diseases. It may also lead to urosepsis in patients with underlying urinary abnormalities. Infections due to $A$. xylosoxidans should be considered in oncology, dialysis, and newborn intensive care units, since it may lead to morbidity and mortality in this group of patients.

\section{Ethics}

Informed Consent: Consent form was filled out by the presented case.

\section{Authorship Contributions}

Surgical and Medical Practices: Aslıhan Demirel, Haluk Akpınar, Data Collection or Processing: Aslıhan Demirel, Interpretation: Aslıhan Demirel, Nur Efe İris, Literature Search: Aslıhan Demirel, Writing: Aslıhan Demirel.

Conflict of Interest: No conflict of interest was declared by the authors.

Financial Disclosure: The authors declared that this study has received no financial support.

\section{References}

1. Steinberg J, Del Rio C. Other gram-negative and gram-variable bacilli. Mandell, Douglas, and Bennett's Principles and Practice of Infectious Disease. 6th ed. Philedelphia: Churchill Livingstone Inc. 2005:2751-68.

2. Manfredi $R$, Nanetti $A$, Ferri $M$, Chiodo F. Bacteremia and respiratory involvement by Alcaligenes xylooxidans in patients infected with the human immunodefiency virus. Eur J Clin Microbiol Infect Dis. 1997:16:933-8.

3. Vu-Thien H, Darbord JC, Moissenet D, Dulot C, Dufourcq JB, Marsol P Garbarg-Chenon A. Investigation of an outbreak of wound infections due to Alcaligenes xylosoxidans transmitted by chlorhexidine in a burns unit. Eur J Clin Microbiol Infect Dis. 1998;17:724-6.

4. Tena D, Carranza R, Barbera JR, Valtezate S, Garrancho JM, Arranz M, SaezNieto JA. Outbreak of long-term intravascular catheter-related bacteremia due to Achromobacter xylosoxidans subspecies xylosoxidans in a hemodialysis unit. Eur J Clin Microbiol Infect Dis. 2005;24:727-32.

5. Hugon E, Marchandin H, Poirée M, Fosse T, Sirvent N. Achromobacter bacteremia outbreak in a paediatric onco-haematology department related to strain with high surviving ability in contaminated disinfectant atomizers. J Hosp Infect. 2015;89:116-22.

6. Turel O, Kavuncuoglu S, Hosaf E, Ozbek S, Aldemir E, Uygur T, Hatipoglu $\mathrm{N}$, Siraneci R. Bacteremia due to Achromobacter xylosoxidans in neonates: clinical features and outcome. Braz J Infect Dis. 2013;17:450-4.

7. Clinical and Laboratory Standarts Institue CLSI (Formerly NCCLS) Performance standards for antimicrobial disk susceptibility tests; approved standard. 9th edition. 2006

8. Yaabuuchi E, Ohyama A. Alcaligenes xylooxidans $\mathrm{n}$. sp. from human ear discharge (Abstract). Jpn J Microbiol. 1971;15:477-81. 
9. Turgutalp K, Kiykim A, Ersoz G, Kaya A. Fatal catheter-related bacteremia due to Alcaligenes (Achromobacter) xylosoxidans in a hemodialysis patient. Int Urol Nephrol. 2012;44:1281-3.

10. Ahmed MS, Nistal C, Jayan R, Kuduvalli M, Anjeet HK. Achromobacter xylosoxidans, an emerging pathogen in catheter-related infection in dialysis population causing prosthetic valve endocarditis: a case report and review of literatüre. Clin Nephrol. 2009;71:350-4.

11. Aisenberg G, Rolston KV, Safdar A. Bacteremia caused by Achromobacter and Alcaligenes species 46 patient with cancer (1989-2003). Cancer. 2004;101:2134-40.

12. Tena $D$, Gonzalez-Praetorius $A$, Perez-Balsalobre $M$, Sancho O, Bisquert J. Urinary tract infection due to Achromobacter xylosoxidans: Report of 9 cases. Scand J Infect Dis. 2008;40:84-7.

13. Van Hal S, Stark D, Marriott D, Harkness J. Achromobacter xylosoxidans subsp. Xylosoxidans prosthetic aortic valve infective endocarditis and aortic root abscesses. J Med Microbiol. 2008;57:525-7. 